\title{
Marx and Manchester: The Evolution of the Socialist Internationalist Free-Trade Tradition, c.1846-1946
}

Marc-William Palen, University of Exeter, email: m.palen@exeter.ac.uk

\begin{abstract}
Socialism is commonly assumed to be antithetical to free trade. This article challenges this misconception by exploring the widespread socialist internationalist support for free trade across the century before the Cold War. The socialist internationalist free-trade tradition evolved alongside and drew inspiration from the Manchester School of economic liberalism. As with any intellectual tradition, socialist internationalist support for free trade was not static. Turn-of-the-century Marxist theorists of imperialism reformulated Marx and Engels's mid-nineteenthcentury free-trade endorsement. Socialist internationalists thereafter increasingly advocated for free trade as a necessary precondition for a more peaceful world order: an ideological marriage that the Manchester School had so famously wedded together in the 1840 s.
\end{abstract}

Keywords: socialist internationalism, free trade, peace, anti-imperialism, Marxism, Manchester School

Wordcount (including footnotes): 11,970

Free trade, or Freihandel, was a hot-button issue at the German Social Democratic Party (SPD) Congress held in Stuttgart in 1898, most notably because of the policy's 
numerous advocates. SPD leader Karl Kautsky kicked things off with a resolution denouncing protectionism for counteracting 'international solidarity.' Luise Zietz, a German feminist and head of the SPD women's movement, seconded Kautsky's call: 'We have to adopt a principled stance, and that is in favor of free trade and against protective tariffs.' August Bebel, SPD chairman and longtime pacifist, followed up on Kautsky and Zietz's free-trade endorsements, and the congress adopted a qualified resolution along these lines. Free trade would receive an even stronger SPD endorsement in 1900 because 'free international exchange is . . before all, a working-class question,' German Marxist revisionist Eduard Bernstein explained in a subsequent letter to London's 1908 International Free Trade Congress. ${ }^{1}$ Their efforts were part of a rich socialist free-trade tradition that began germinating when Friedrich Engels and Karl Marx migrated to Britain in the 1840s, just as the island-nation was embracing free trade as both policy and ideology. The same British free-trade embrace was also giving rise at this time to the Manchester School (Manchester liberalism, Cobdenism), an economic ideology that tied international trade liberalization together with cheap food, democratization, anti-imperialism, and peace - a cosmopolitan concoction that socialist internationalists increasingly imbibed by the turn of the century. ${ }^{2}$

Recovering the free-trade dimensions of socialist internationalism, and the pacific influence of Britain's Manchester School upon it, upends the commonly held assumption that socialists the world over have supported nationalism and

\footnotetext{
${ }^{1}$ Protokoll über die Verhandlungen des Parteitages der Sozialdemokratischen Partei Deutschlands, Stuttgart (Berlin, 1898), 68, 200; Carlton J. H. Hayes, 'The History of German Socialism Reconsidered', American Historical Review 23 (1917), 93-94; Cornelius Torp, The Challenges of Globalization: Economy and Politics in Germany, 1860-1914 (New York, 2014), 248; Report of the Proceedings of the International Free Trade Congress, London, August, 1908 (London, 1908), 28.

${ }^{2}$ On the long-term role of Manchester School ideology within Britain and its empire, see especially William Dyer Grampp, The Manchester School of Economics (Stanford, 1960); Anthony Howe, Free Trade and Liberal England, 1846-1946 (Oxford, 1997); Frank Trentmann, Free Trade Nation: Commerce, Consumption, and Civil Society in Modern Britain (Oxford, 2008).
} 
protectionism amid their collectivist opposition to free-market capitalism. ${ }^{3}$ Doing so also provides a much-needed prehistory to the growing body of literature on 'socialist globalization'. This scholarship has focused primarily on socialist attempts to deepen regional and global interdependence through market integration and supranational governance amid the Manichean ideological divide of the Cold War. ${ }^{4}$ By contrast, earlier attempts have received far less attention, and the role of free trade within the socialist internationalist tradition less still. As a partial corrective, this article traces the evolution of socialist internationalist support for free trade across the century before the Cold War, wherein the cosmopolitan subscription to free trade increasingly made strange bedfellows among those capitalists and socialists seeking a more interdependent and peaceful world order.

The global turn to economic nationalism from the late nineteenth century to the Second World War played a crucial role in aligning the ideological schools of Marx and Manchester. By the 1860s and 1870s, many industrializing capitalist states - most prominent among them the United States and Germany — embraced policies of 'infant industrial' protectionism and went in search of new colonial markets among the underdeveloped regions of Africa, Latin America, and the Asia Pacific. ${ }^{5}$ The close connection between these protectionist and imperial developments helped spark the growth of socialist theories of imperialism and socialist free-trade-and-peace

\footnotetext{
${ }^{3}$ See, for example, Friedrich Hayek, Individualism and Economic Order (Chicago, 1948), 270-71; Michael A. Heilperin, Studies in Economic Nationalism (Paris, 1960), 43.

${ }^{4}$ See, for instance, Humanity's Spring 2015 special issue 'Toward a History of the New International Economic Order'; Oscar Sanchez-Sibony, Red Globalization: The Political Economy of the Soviet Cold War from Stalin to Khrushchev (Cambridge, 2014); Johanna Bockman, Markets in the Name of Socialism: The Left-Wing Origins of Neoliberalism (Stanford, 2011); James Mark, Bogdan Iacob, Tobias Rupprecht, and Ljubica Spaskovska, 1989: A Global History of Eastern Europe (Cambridge, 2019).

${ }^{5}$ See, et al., Ha-Joon Chang, Kicking Away the Ladder: Development Strategy in Historical Perspective (London, 2002); Henryk Szlajfer, Economic Nationalism and Globalization, trans. by Maria Chmielewska-Szlajfer (Leiden, 2012).
} 
activism. ${ }^{6}$ After the First World War, an even stronger global swing towards economic nationalism and imperial retrenchment encouraged the widespread socialist internationalist backing of capitalist supranational initiatives like the League of Nations and European union in the hopes of facilitating free trade, decolonization, and world peace. ${ }^{7}$

Until now, socialist internationalist sympathy for free trade and its close association with anti-imperialism and peace in the century before the Cold War has yet to be collectively examined. Doing so uncovers how this socialist internationalist free-trade tradition evolved alongside and drew inspiration from the Manchester School of economic liberalism. Of course, as with any intellectual tradition, socialist internationalist support for free trade was not static. Turn-of-the-century Marxist theorists of imperialism began reformulating Karl Marx and Friedrich Engels's midnineteenth-century free-trade endorsement. Socialist internationalists during and after the First World War increasingly advocated for free trade as a necessary precondition for a more peaceful world order — an ideological marriage that the Manchester School had so famously wedded together in the 1840 s.

\section{Marx, Engels, and the Manchester School}

\footnotetext{
${ }^{6}$ Bert F. Hoselitz, 'Socialism, Communism, and International Trade', Journal of Political Economy 57 (1949), 227-241; Michael Howard and John Edward King, A History of Marxian Economics, Volume I, 1883-1929 (Princeton, 1989), 90-92; Pranab Bardhan, 'Marxist Ideas in Development Economics: A Brief Evaluation', Economic and Political Weekly 20 (30 March 1985), 550; Claudio Katz (trans. by Carlos Perez), 'The Manifesto and Globalization', Latin American Perspectives 28 (2001), 7-8; Bill Dunn, Neither Free Trade Nor Protection: A Critical Political Economy of Trade Theory and Practice (Cheltenham, 2015), chap. 5.

${ }^{7}$ This line of thought bore more than a few similarities to that of their interwar 'neoliberal' contemporaries. See, for instance, Ben Jackson, 'At the Origins of Neo-Liberalism: The Free Economy and the Strong State, 1930-1947', Historical Journal 53 (March 2010): 129-151; Quinn Slobodian, Globalists: The End of Empire and the Birth of Neoliberalism (Cambridge, MA, 2018).
} 
The socialist free-trade tradition began taking shape in the 1840s, just as Britain unilaterally abandoned protectionism following a prolonged grassroots free-trade campaign centered in Manchester. The island-nation's political and ideological shift to free trade sparked a brief transatlantic flirtation with trade liberalization. ${ }^{8}$ This was due in no small part to the transnational influence and activism of Britain's Manchester School, which asserted that free-trade internationalism wrought a panoply of cheap food, democratization, anti-imperialism, and peace. ${ }^{9}$ Free trade appealed to the cosmopolitan's ideological and material interests alike by promising to feed the world's poor with cheap food and to undermine the militant political influence of atavistic landed elites. This one-two punch would, free traders promised, result in global interdependence, political enfranchisement, prosperity, and geopolitical amity. As Richard Cobden (1804-1865), the mid-nineteenth-century leader of the Manchester School, outlined in a January 1846 speech to the thousands of supporters packed inside Manchester's Free Trade Hall, 'I see in the Free-trade principle that which shall act on the moral world as the principle of gravitation in the universe,--drawing men together, thrusting aside the antagonism of race, and creed, and language, and uniting us in the bonds of eternal peace.' As a result, his envisaged interdependent economic order would also undermine imperialism and militarism by eliminating 'the desire and the motive for large and mighty empires; for gigantic

\footnotetext{
${ }^{8}$ C. P. Kindleberger, 'The Rise of Free Trade in Western Europe, 1820-1875', Journal of Economic History 35 (March 1975): 20-55; Scott C. James and David A. Lake, 'The Second Face of Hegemony: Britain's Repeal of the Corn Laws and the American Walker Tariff of 1846', International Organization 43 (Winter 1989): 1-29.

${ }^{9}$ On the transnational spread of Manchester School ideas, see Howe, Free Trade and Liberal England; Anthony Howe and Simon Morgan, eds., Rethinking Nineteenth-Century Liberalism: Richard Cobden Bicentenary Essays (Burlington, VT, 2006); Marc-William Palen, The 'Conspiracy' of Free Trade: The Anglo-American Struggle over Empire and Economic Globalisation, 1846-1896 (Cambridge, 2016).
} 
armies and great navies. ${ }^{10}$ Cobden's pacific free-trade vision briefly found a receptive mid-nineteenth-century transatlantic audience.

Karl Marx (1818-1883) and Friedrich Engels (1820-1895), based in England from the 1840s onwards, observed this shift from protectionism to free trade in Britain and some of the other Western capitalist states - and they gave it their qualified endorsement. ${ }^{11}$ Marx and Engels viewed the international turn to free trade as an advancement of the global capitalist project, the dawn of a new epoch of capitalist internationalism. For Marx, free trade was a progressive condition of industrial capitalism, moving it a step closer to socialist revolution. Protectionism, by contrast, was regressive and belonged to the pre- and proto-industrial capitalist era. ${ }^{12}$ For Marx's close friend and patron Friedrich Engels, too, free trade was preferable to protectionism as the former would 'expand as freely and as quickly as possible' the capitalist system and thus hasten the destruction of 'the whole system. ${ }^{13}$ Marx, soon before his relocation to Britain in the 1840s, also presaged subsequent twentiethcentury socialist free-trade support for supranational governance. Noting the centuries-long regressive political influence of British protectionist elites, Marx speculated that 'only by a congress of nations' would free traders be able to surmount national protectionist tendencies. ${ }^{14}$ Thus by the time Marx and Engels were

\footnotetext{
${ }^{10}$ Richard Cobden, Speeches on Questions of Public Policy, Vol. 1, ed. by John Bright and James E. Thorold Rogers (London, 1870), 362-363.

${ }^{11}$ Debates surrounding 'material interests' in early-1840s Germany informed Marx's later free-trade position. Karl Marx, A Contribution to the Critique of Political Economy (Chicago, 1904 [1859]), 10. ${ }^{12}$ On the Irish exception, see Marx to Engels, 30 Nov. 1867, reprinted in Karl Marx and Frederick Engels: Selected Correspondence, 1846-1895 (New York, 1942), 229.

${ }^{13}$ Reza Ghorashi, 'Marx on Free Trade', Science \& Society 59 (Spring 1995), 43; Howard and King, A History of Marxian Economics, Vol. 1, 15; Samuel Hollander, The Economics of Karl Marx: Analysis and Application, 445-446; Hollander, Friedrich Engels and Marxian Political Economy (Cambridge, 2011), 132-134, 233, 275, 359-361; Friedrich Engels, preface to Karl Marx, On the Question of Free Trade (1888), Marx \& Engels Collected Works [MECW] vol. 25, 521; Bert F. Hoselitz, 'Socialism, Communism, and International Trade', Journal of Political Economy 57 (June 1949), 233.

${ }^{14}$ Karl Marx, 'The Industrialists of Hanover and Protective Tariffs', (22 Nov. 1842), MECW Vol. 1, 286.
} 
headquartered in 'Free Trade England,' they began anticipating, as Claudio Katz puts it, 'the present process of globalization' through their 'descriptions of the creation of a world market, economic cosmopolitanism, the universal extension of commercial rules, and the destruction of tariff barriers. ${ }^{15}$

The mid-century hegemonic rise of Manchester liberalism in Britain informed Marx and Engels's free-trade sympathies. This should not be all that surprising considering that both men spent most of their lives in England from the 1840s onward. Engels himself claimed to have heard the leaders of the Anti-Corn Law League (ACLL, 1839-1846) — Britain's main free-trade pressure group that Cobden spearheaded — 'pour forth their Anti-Corn-Law arguments more than a hundred times' following Engels's arrival in Manchester. He and Marx also predicted that the ACLL's efforts would have the added benefit of bringing down the landed aristocracy, thereby providing a much-needed boon to English tenant farmers. ${ }^{16}$ So, too, did Marx and Engels's connecting of protectionism with the rise of monopolies, trusts, and geopolitical tensions contain more than a few of the internationalist trappings of the Manchester School.

But while Marx and Engels may have shared a similar distaste for protectionism, unlike the Manchester School they did not consider free trade free of $\sin$. Neither man believed that free trade was a true friend of the proletariat. They assumed that cheaper prices wrought from free trade also meant lower wages for the workingman and that the free market's boom-bust economic cycle and overproduction were no boon to workers. But the most important difference between them and the Manchester School arose in where they placed free-trade

\footnotetext{
${ }^{15}$ Katz, 'The Manifesto and Globalization', 5.

${ }^{16}$ Frederick Engels, 'The Free Trade Congress at Brussels', MECW Vol. 6, 1845-48 (London, 1976), 283; Engels, 'The Corn Laws', (22 Dec. 1842), MECW Vol. 2, 1838-42 (London, 1987), 380-82; W. O. Henderson, The Life of Friedrich Engels Volume 1 (London, 1976), 95.
} 
internationalism within the stages of capitalist development; Marx and Engels considered free trade to be a progressive capitalist stage along the path towards eventual socialist revolution, whereas Manchester liberals viewed free trade's universal adoption, and the consequent prosperity and peace that would follow, as the final stage of capitalist development. At the geopolitical level, Marx was more skeptical than later free-trade socialists concerning the Manchester School premise that market interconnectivity derived from trade liberalization would unite the world in a fraternity of nations. Marx also thought the 'squint-eyed set of Manchester humbugs' were hypocritical in condemning war abroad while ignoring the domestic war on workers at home. ${ }^{17}$

Despite these limits to Marx and Engels's free-trade internationalism, they gave it their support. 'We are for Free Trade,' Marx declared to his Brussels audience in 1847 , because the large-scale internationalization of trade across 'the territory of the whole earth' would not only connect the world's markets - it would also help unite the world's proletariat. He also granted that free trade increased productive capital, which would increase the demand for labor and thereby further lay the groundwork for the proletarian revolution: 'It breaks up old nationalities and pushes the antagonism of the proletariat and the bourgeoisie to the extreme point. In a word, the Free Trade system hastens the Social Revolution. ${ }^{18}$ While Marx and Engels were not certain that free trade would unite the nations of the world, they were confident that it would unite the world's workers.

\footnotetext{
17 'Marx on Free Trade', 46; Karl Marx, The Eastern Question: A Reprint of Letters Written 18531856 Dealing with the Events of the Crimean War, ed. by Eleanor Marx Aveling and Edward Aveling (London and New York, 2013 [1897]), 151; James Joll, 'The Second International and War', Publications de l'École Française de Rome 54 (1981), 247.

${ }^{18}$ Karl Marx, 'Speech of Dr. Marx on Protection, Free Trade, and the Working Classes', Northern Star (9 Oct. 1847), reprinted in MECW Vol. 6, 290; Jorge Larrain, 'Classical Political Economists and Marx on Colonialism and 'Backward' Nations', World Development 19 (Feb.-March 1991), 230-231; Alan Gilbert, 'Marx on Internationalism and War', Philosophy \& Public Affairs 7 (Summer 1978): 346-369.
} 
While Marx and Engels avoided speculating about an ideal socialist trade policy, their internationalist vision of the end of the nation-state after the socialist revolution shared much in common with the free-trade vision of the Manchester School. After all, for Marx and Engels the end of nation states would have meant the end of protectionism between nation states. Manchester School adherents similarly envisaged the gradual decline of the nation state, and with it the elimination of national rivalries and trade barriers. ${ }^{19}$ Both intellectual camps therefore overlapped in their predictions for the demise of national boundaries and national rivalries, with free world trade an end result.

The hegemonic influence of the Manchester School also helps explain why, in the Communist Manifesto and elsewhere in the late 1840s, Marx and Engels directed their most scathing critiques upon Germany's economic nationalist turn to 'infant industrial' protectionism rather than upon newly minted 'Free Trade England'. Marx charged that, instead of moving capitalism towards socialist revolution, Germany's protectionism was moving it backwards: 'People are thus about to begin in Germany with what people in France and England are about to end. The old corrupt conditions against which these countries are rebelling in theory and which they only bear as one bears chains, is greeted in Germany as the dawn of a beautiful future.' Marx singled out the protectionist theories of Friedrich List (1789-1846) in particular, while also broadly condemning German protectionism and its manipulative call to patriotism for allowing the bourgeoisie to 'exploit his fellow-countrymen.' ${ }^{20}$ Marx emphasized that

\footnotetext{
${ }^{19}$ Per A. Hammarlund, Liberal Internationalism and the Decline of the State: The Thought of Richard Cobden, David Mitrany and Kenichi Ohmae (New York, 2005); Mark Mazower, Governing the World: The History of an Idea (New York, 2012), chap. 2.

${ }^{20}$ Italics in the original. Karl Marx, 'Draft of an Article on Friedrich List's Book: Das Nationale System der Politischen Oekonomie', MCWE, Vol. 4: Marx and Engels 1844-45 (London, 2010), 275. See also Karl Marx, 'Speech of Dr. Marx on Protection, Free Trade, and the Working Classes', Northern Star (9 Oct. 1847), reprinted in Marx \& Engels Collected Works Volume 6: Marx
} 
protectionism 'forcibly' abbreviated 'the transition from medieval to the modern mode of production,' and, if allowed to progress naturally, would soon be replaced by free trade as the next stage of capitalist development. Engels shared Marx's criticisms of German protectionism. ${ }^{21}$

Marx and Engels, again sounding very much like their Manchester School contemporaries, considered protectionism harmful to the international system and the prime suspect for creating monopolies and trusts. As early as 1842 , seven years before he moved to London, Marx began to decry protectionism as 'the organization of a state of war in time of peace, a state of war which, aimed in the first place against foreign countries, necessarily turns in its implementation against the country which organizes it. ${ }^{22}$ Engels, though initially more sympathetic to List's arguments, soon came around to Marx's position, and argued well into the 1880 s that the creation of monopolies and trusts provided 'the surest sign that protection has done its work and is changing its character.' Engels denounced protectionism for being

at best an endless screw, and you never know when you have done with it. By protecting one industry, you directly or indirectly hurt all others, and have therefore to protect them too. By so doing you again damage the industry that you first protected, and have to compensate it ... and so on ad infinitum.

and Engels 1845-48 (London, 2010), 287-290; Roman Szporluk, Communism and Nationalism: Karl Marx versus Friedrich List (Oxford, 1988); Radhika Desai, 'Marx, List, and the Materiality of Nations', Rethinking Marxism 24 (2012): 47-67.

${ }^{21}$ MECW vol. 35, 744; Hollander, Engels and Marxian Political Economy, 132-134.

${ }^{22}$ Marx, 'Industrialists of Hanover', MECW Vol. 1, 286; Edmund Silberner, The Problem of War in Nineteenth Century Economic Thought (Princeton, 1946), 261-262. 
The necessary turn 'to Free Trade is immensely more difficult' and necessitated a 'fight.' Germany had perverted this order, leading to the rise of trusts and landed monopolies. ${ }^{23}$ Marx and Engels thus gave their pragmatic socialist endorsement to the productivity and internationalism that capitalist free trade created: and the eventual global proletarian revolution it would help foster. ${ }^{24}$ Marx and Engels's socialist focus on the stages of capitalist trade policy from the late 1840s onward became even more prevalent among turn-of-the-century Marxist theorists, succumbing as they did to the cosmopolitan influence of Manchester liberalism. ${ }^{25}$

\section{Free Trade and Socialist Theories of Imperialism}

Marx and Engels had undertaken much of their theorizing about the stages of capitalism amid an era marked by a brief transatlantic turn to trade liberalization and the growing popularity of the Manchester School. ${ }^{26}$ But this short-lived midnineteenth-century international trend toward freer trade underwent a sharp reversal in the latter half of the nineteenth century. Protectionism became the preferred policy for developing nations like Germany, the United States, Russia, and Japan as the century drew to a close, due in large part to a surge in industrialization and national consolidation, coupled with the onset of a series of global economic depressions between 1873-96. The List-inspired German Historical School, for example, overtook the German imperial government and universities in the 1870 s and 1880 s to

\footnotetext{
${ }^{23}$ George Lichtheim, Marxism: An Historical and Critical Study (New York, 1961), 216; Frederick Engels, preface to the 1888 American edition of Karl Marx's On the Question of Free Trade, available online at https://www.marxists.org/archive/marx/works/1888/free-trade/.

${ }^{24}$ Mori Kenzo argues that Marx's views on free trade changed with respect to some developing countries in "Marx and "Underdevelopment": His Thesis on the "Historical Roles of British Free Trade" Revisited', Annals of the Institute of Social Science 19 (1978): 35-61.

${ }^{25}$ Hoselitz, 'Socialism, Communism, and International Trade', 227; Howard and King, A History of Marxian Economics, Vol. 1, 15-16, 91.

${ }^{26}$ Howe and Morgan, eds., Rethinking Nineteenth-Century Liberalism.
} 
counteract the spread of Manchestertum (the German epithet for the Manchester School). ${ }^{27}$ Similarly, in the United States, the Republican Party rebranded itself after 1865 as the party of economic nationalism and steered US foreign trade policy along its protectionist course until the 1930s. Even among Britain's own settler colonies, protectionist policies became entrenched by the turn of the century. While free trade kept its hold upon Britain, economic nationalism gripped the developing world, as did the monopolistic rise of trusts and cartels and a new wave of Western colonialism in Africa, Latin America, and Asia.

For turn-of-the-century socialist theorists of imperialism like Rudolf Hilferding, Vladimir Lenin, Karl Kautsky, and Eduard Bernstein, these protectionist, monopolistic, and imperial trends were interrelated. They accordingly honed their theories of imperialism from within this evolving Marxist free-trade tradition, and updated it to account for the turbulent, protectionist, and militant world order. ${ }^{28}$ They at once critiqued protectionism for being a root cause of monopoly capitalism and imperialism - much like contemporary non-Marxist theorists - while at the same time they inverted Marx and Engels's stages of capitalist trade development.

Austria's Rudolf Hilferding (1877-1941) like Marx and Engels, favored free trade over protectionism. In Finance Capital (1910), Hilferding wrote that undoubtedly 'free trade would amalgamate the whole world market into a single economic territory. Free trade would also ensure the highest possible labour productivity and the most rational international division of labour. ${ }^{29}$ Hilferding also

\footnotetext{
${ }^{27}$ Erik Grimmer-Solem, The Rise of Historical Economics and Social Reform in Germany, 1864-1894 (New York, 2003); José Luís Cardos and Michalis Psalidopoulos, eds., The German Historical School and European Economic Thought (New York, 2016); Keith Tribe, Strategies of Economic Order: German Economic Discourse, 1750-1950 (Cambridge, 1995).

${ }^{28}$ Howard and King, A History of Marxian Economics, Vol. 1, chap. 5.

${ }^{29}$ Hilferding, Finance Capital (1910), reprinted in P. J. Cain and Mark Harrison, eds., Imperialism:

Critical Concepts in Historical Studies Vol. 1 (London, 2001), 227.
} 
granted that protectionism, not free trade, went hand-in-hand with imperialism. ${ }^{30}$ But Hilferding broke from Marx and Engels by portraying protectionism as a progressive rather than a regressive developmental stage of capitalism: a successor to the midcentury free-trade epoch rather than its antecedent. Protectionism had created the monopolies, the market inefficiencies, the disparities of wealth between rich and poor, and the friction between the imperial powers that were now paving the way towards the proletarian revolution. The protectionist rise of finance capital and the resulting imperial rivalries were now seen as an inevitable step forward in the stages of capitalism. In other words, by making protectionism the successor to free trade, turn-of-the-century revolutionary theorists of imperialism like Hilferding could claim that the twin international rise of protectionism and financial monopolies was the latest, or even the highest, stage of capitalism. Hilferding could also claim that the need of these same protectionist nations to export surplus capital to new markets and to obtain raw materials naturally led to imperial capitalist conflict. His progressive placement of protectionism within the capitalist stages was thus a critical point of departure for his and subsequent Marxist theories of imperialism. Hilferding's inversion of Marx and Engels's capitalist stages - of free trade preceding rather than succeeding protectionism - and Hilferding's theory of the cartel tariff thereafter reappeared in the work of Russian theorist Vladimir Lenin (1870-1924).

Lenin's evolving imperial theory leaned upon Marx, Engels, and Hilferding, as well as 'new' Manchester liberal J. A. Hobson. Like Marx and Engels, Lenin had at first placed free trade as the next progressive stage of capitalism, but came around to the stage theory of Hilferding. ${ }^{31}$ In 1895 , Lenin was demanding that 'Russian

\footnotetext{
${ }^{30}$ Hilferding, Finance Capital; Lichtheim, Marxism, 310-312.

${ }^{31}$ Howard and King, A History of Marxian Economics, Vol. 1, chap. 13.
} 
Marxists must stand for free trade, since the reactionary character of protection, which retards the country's economic developments, and serves the interests . . of a handful of all-powerful magnates ... and since free trade means accelerating the process that yields the means of deliverance from capitalism. ${ }^{32}$ But by 1916 , with the world's empires at war, this free-trade progression fell by the wayside; Lenin now asserted that the rest of the industrializing world, 'sheltering themselves with 'protective' tariffs,' had undermined Britain's more pacific free-trade policies. And he famously proclaimed the present protectionist monopoly stage to be capitalism's last. ${ }^{33}$ Lenin's theory of imperialism was an explicit combination of Marx and Manchester. While Lenin admitted to borrowing heavily from Hilferding, he also acknowledged his intellectual debt to British Manchester liberal J. A. Hobson, whose Imperialism: A Study (1902) condemned the protectionist international system for creating the market inefficiencies that led to the imperial search for raw materials and new markets for surplus capital. The overlap between their theories was such that it has been dubbed the 'Hobson-Lenin Thesis.' 34

The free-trade sympathies of German socialist imperial theorist and SPD leader Karl Kautsky (1854-1938) went even further in combining Manchester liberalism with Marxism. Kautsky's support for free trade remained remarkably consistent, and was tied closely to his antipathy towards German protectionism and colonialism. ${ }^{35}$

\footnotetext{
${ }^{32}$ V. I. Lenin, The Economic Content of Narodism and the Criticism of it in Mr. Struve's Book (1895), in V. I. Lenin: Collected Works Vol. 1 (Moscow, 1971), 441.

${ }^{33}$ Lenin, Imperialism, 71.

${ }^{34}$ V. I. Lenin, Imperialism: The Highest Stage of Capitalism (Sydney, 1999 [1916]), 111; A. M. Eckstein, 'Is There a "Hobson-Lenin Thesis" on Late Nineteenth-Century Colonial Expansion?' Economic History Review 44 (May 1991): 297-318. On Hobson's influence on Lenin, see also Brewer, Marxist Theories of Imperialism; D. H. Kruger, 'Hobson, Lenin and Schumpeter on Imperialism', Journal of the History of Ideas 16 (1955): 252-259; John Willoughby, 'Evaluating the Leninist Theory of Imperialism', Science \& Society 59 (Fall 1995): 320-338.

35 John H. Kautsky, Karl Kautsky: Marxism, Revolution \& Democracy (New Brunswick and London, 1994), 143-44; L. Meldolesi, 'The Debate on Imperialism Just Before Lenin', Economic and Political Weekly 19 (20-27 Oct. 1984): 1833-1839.
} 
His time spent in London from 1885 to 1890 proved formative, leading to a close relationship with Friedrich Engels, as well as an intellectual infatuation with the Manchester School. ${ }^{36}$ His association of 'industrial capitalism' with free trade, peace, and progress — and protectionism with pre-industrialism and militarism — reflected the theories of non-Marxist contemporaries like Hobson and Joseph Schumpeter. ${ }^{37}$ Right around the same time as Hobson was penning Imperialism, Kautsky was drawing similar inspiration from what he perceived as the decline of Manchester liberalism in Britain, resulting in the outbreak of the second Boer War (1899-1902). 'Manchester ideals' were being 'pushed into the background by Imperialism,' Kautsky wrote in 1900, thereby increasing 'the power of militarism.' And like Hobson, he observed how colonialism after 1870 followed from the search for new markets as outlets for surplus goods and capital - surpluses wrought from inefficient protectionist policies. 'The higher the tariff barriers between individual capitalist states grow, the more each of them feels the need to assure itself of a market which no one can exclude them from, and to gain supplies of raw material which no one can cut off,' thereby creating an 'arms race' that 'must grow ever greater and the danger of a world war come ever nearer.' In his 1914 article 'Ultra-imperialism,' he associated free trade with peace and industrial capitalism, and contrasted them with

\footnotetext{
${ }^{36}$ Lichtheim, Marxism, 275; Kautsky, Kautsky, 14.

${ }^{37}$ Paul Probert, "“Our Natural Ally": Anglo-German Relations and the Contradictory Agendas of Wilhelmine Socialism, 1897-1900', in Geoff Eley and James Retallack, eds., Wilhelminism and Its Legacies (Oxford and New York, 2008), 126; L. Meldolesi, 'The Debate on Imperialism Just before Lenin', Economic and Political Weekly 19 (3 Nov. 1984), 1876; John H. Kautsky, 'J. A. Schumpeter and Karl Kautsky: Parallel Theories of Imperialism', Midwest Journal of Political Science 5 (May 1961): 101-128; P. J. Cain, 'Capitalism, Aristocracy and Empire: Some 'Classical' Theories of Imperialism Revisited', Journal of Imperial and Commonwealth History 35 (March 2007): 25-47. Hobson and Schumpeter also owed an intellectual debt to Kautsky and other contemporary Marxist theorists of imperialism and monopoly capitalism. See, for instance, Ricardo Villanueva, 'Hobson's Theory of Imperialism and its Indebtedness to Socialism: A Challenge to Conventional Narratives of Early International Relations', Australian Journal of Politics and History 63 (2017): 508-523; Nathan Rosenberg, 'Was Schumpeter a Marxist?' Industrial and Corporate Change 20 (Aug. 2011): 12151222; Panayotis Michaelides \& John Milios, 'Did Hilferding Influence Schumpeter?' History of Economics Review 41 (2005): 98-125; Kautsky, 'Schumpeter and Kautsky'.
} 
the connection between protectionism, cartels, financial capitalism, and the consequent need to export surplus capital: 'the principal roots of imperialism' that had 'replaced free trade. ${ }^{38}$ Kautsky therefore roundly condemned colonialism derived from protectionism. ${ }^{39}$ Kautsky's Marx-Manchester ideology also informed his belief that European trade liberalization could only maintain peace through supranational governance. He argued that a free-trading 'United States of Europe' would 'ban the spectre of war.' ${ }^{40}$ Kautsky's support for free trade, supranational governance, and peace - positions scholars more commonly associate with interwar 'neoliberal' intellectuals - continued to influence the SPD in the interwar years and beyond. $^{41}$

Eduard Bernstein, an SPD spokesman on foreign policy and taxation issues in the German Reichstag from 1902-28, even more than Kautsky epitomized the confluence of Manchestertum and Marxism in Germany. ${ }^{42}$ Bernstein's formative years of exile in London (1888-1901) placed him at the center of turn-of-the-century Marxist and Manchester School radicalism. Bernstein's time in England, rubbing shoulders with Kautsky, Engels, and the Fabians, as well as Cobdenites like Hobson, had a profound influence upon his later socialist free-trade internationalism. ${ }^{43}$ Manfred Steger has gone so far as to state that Bernstein fell 'under the influence of

\footnotetext{
${ }^{38}$ Karl Kautsky, 'Ultra-Imperialism', (1914), reprinted in New Left Review lix (1970), 42, 44.

${ }^{39}$ Dick Geary, Karl Kautsky (Manchester, 1987), 32, 46; Karl Kautsky, 'Socialism and Colonial Policy', Worker's Liberty Magazine (1907), 103-104, 107, 122; John Milios and Dimitris P. Sotiropoulos, Rethinking Imperialism: A Study of Capitalist Rule (London, 2009), 60-61; Mike Macnair, Karl Kautsky on Colonialism (London, 2013), 15.

${ }^{40}$ Brian Shaev, 'Liberalising Regional Trade: Socialists and European Economic Integration', Contemporary European History 27 (May 2018), 261.

${ }^{41}$ Mike Macnair, Kautsky on Colonialism, 29.

${ }^{42}$ On the broader influence of the Manchester School on German liberalism, see Detlev Mares, 'Not Entirely a Manchester Man: Richard Cobden and the Construction of Manchesterism in NineteenthCentury German Economic Thinking', in Howe and Morgan, eds., Rethinking Nineteenth-Century Liberalism, 141-160; Julius Becker, Das Deutsche Manchestertum: Eine Studie Zur Geschichte Des Wirtschaftspolitischen Individualismus (Karlsruhe, 1907).

${ }^{43}$ Howard and King, A History of Marxian Economics, 92; Becker, Das Deutsche Manchestertum, 99.
} 
both Engels and the British free-trade tradition. ${ }^{44}$ Like Kautsky, Bernstein was consistent in his support for free trade over the course of his socialist political career. Bernstein believed free trade was not only progressive but also good for both the proletariat and the bourgeoisie. Also like Kautsky (and Marx), Bernstein condemned List-inspired 'infant industrial' protectionism for creating geopolitical tensions and for being reactionary and atavistic, a throwback to the era of mercantilism and a stumbling block to modernization. His critique of militarism - for which he blamed jingoism, nationalism, protectionism, and the undue influence of arms manufacturers on German policymaking — owed much to the influence of later Engels. And like Kautsky, Bernstein's critique shared much in common with Hobson and Schumpeter, as did his belief that free trade and industrialism were the foundation stones of a peaceful economic order, such that R. A. Fletcher posits that Bernstein was 'not only fundamentally more British than German but also thoroughly imbued with the values of Cobdenite radicalism. ${ }^{45}$ Bernstein's Marx-Manchester free-trade beliefs would find wide-ranging subscribers among early-twentieth-century socialist internationalists. $^{46}$

III. Socialist Free-Trade-and-Peace Activism, c. 1880-1918

Socialist free-trade-and-peace activism grew substantially between the turn of the century and the end of the First World War, a period that uncoincidentally also saw

\footnotetext{
${ }^{44}$ Manfred Steger, The Quest for Evolutionary Socialism: Eduard Bernstein and Social Democracy (Cambridge, 1997), 206.

${ }^{45}$ R. A. Fletcher, 'Cobden as Educator: The Free-Trade Internationalism of Eduard Bernstein, 18991914', American Historical Review 88 (June 1983), 562; Fletcher, 'Bernstein in Britain: Revisionism and Foreign Affairs', International History Review 1 (July 1979): 349-375.

${ }^{46}$ Eduard Bernstein, 'German Professors and Protectionism', Contemporary Review (1904): 18-31; R. A. Fletcher, 'In the Interest of Peace and Progress: Eduard Bernstein's Socialist Foreign Policy', Review of International Studies 9 (April 1983), 79-80, 82-84; Fletcher, 'Cobden as Educator', 564-68, 572.
} 
the growth of protectionism, monopolies, and colonial expansion. In contrast to the rest of the industrializing world, within turn-of-the-century Britain, free trade had evolved into a cause, and Richard Cobden a popular hero, among the working class. Socialist leaders of the British trade union movement and the Independent Labour Party (ILP) remained supportive of the Manchester School's belief that free trade mollified geopolitical conflict, owing to the decades-long relationship between the nation's working class and Liberal radicals. ${ }^{47}$ 'ILP's internationalism,' Paul Bridgen observes, 'was influenced more by the nineteenth-century liberal internationalist campaigns of Cobden and Gladstone than by the anti-national internationalism of socialism. $^{48}$

German socialist internationalists, imbued with their own Marx-Manchesterinspired notions, appear to have been even more proactive than their British counterparts amid their opposition to Germany's protectionist imperial government. By 1879 , a unified German state had turned to an economic nationalist program of infant industrial protectionism along lines first laid out by Friedrich List in the 1840s, which Marx had previously condemned as retrograde in the capitalist stages of development. From the 1890s, opposition SPD leaders like Engels, Kautsky, Bernstein, Zietz, and Bebel began advocating instead for free trade in their struggle

\footnotetext{
47 These trade union leaders included, among others, Arthur Henderson, a founding member of the Labour Party, J. R. Clynes of the National Union of General Workers (and a member of the Labour Party Executive Committee from 1904-1939), G. H. Wardle of the Railwaymen's Union, and Tom Shaw of the Textile Trades Federation. Paul Bridgen, The Labour Party and the Politics of War and Peace, 1900-1924 (London, 2009), 38-39; Jean Gaffin and David Thoms, Caring \& Sharing: he Centenary of the Co-Operative Women's Guild (Manchester, 1983), 54-55; Paul Laity, The British Peace Movement 1870-1914 (Oxford, 2002), 10.

${ }^{48}$ Bridgen, Labour Party and Politics of War and Peace, 24, 38-39; Robert E. Dowse, 'The Entry of the Liberals into the Labour Party, 1910-1920', Bulletin of Economic Research 13 (Nov. 1961), 85. See also Anthony Howe, 'Towards the "Hungry Forties": Free Trade in Britain, c. 1880-1906', in E. F. Biagini, ed., Citizenship and Community: Liberals, Radicals and Collective Identities in the British Isles, 1865-1931 (Cambridge, 1996), 194, 208; Howe, Free Trade and Liberal England, 264; D. J. Newton, British Labour, European Socialism and the Struggle for Peace, 1889-1914 (Oxford, 1985); Kenneth E. Miller, Socialism and Foreign Policy: Theory and Practice in Britain to 1931 (The Hague, 1967).
} 
against the avowedly anti-Manchestertum protectionist policies of the German Historical School and Wilhelm's imperial government. ${ }^{49}$ As in Edwardian Britain, albeit with less success, the German socialist fight for free trade promised to provide cheap food for the working class and to undermine the power of the landed elite (the Junckers), the nation's foremost imperial protectionists. As a result, by 1902 the SPD even found themselves allied with the country's sidelined liberal Progressives. 'The link between them,' George Lichtheim notes, 'was of course free trade. ${ }^{50}$

Germany's Marx-Manchester free traders were thereafter instrumental in shaping the free-trade-and-peace programs of the international socialist congresses in Copenhagen (1910) and Basel (1912). Both programs foreshadowed Woodrow Wilson's subsequent Fourteen Points, including a call for 'no economic war after the war ... freedom of the seas ... and the most rapid possible extension of the policy of free trade in the colonies as well as in the home land.' At the 1912 congress, Bebel and Kautsky received support from Bebel's new SPD co-chairman, Hugo Haase, who observed that "economic interdependence constitutes a force that restricts belligerent agitators.' Bernstein, in turn, called for a 'protest against protectionism, a demonstration in favor of peace, freedom, and free trade. ${ }^{51}$ Just a month into the First World War, Kautsky accordingly laid out three principles for socialist internationalists to support in any peace negotiations that exemplified the evolving

\footnotetext{
${ }^{49}$ Becker, Das deutsche Manchestertum; Fletcher, 'Cobden as Educator'; Torp, Challenges of Globalization; Volker Hentschel, Die Deutschen Freihändler und der Volkswirtschaftlich Kongress 1858 bis 1885 (Klett, 1975), 17-22. Belgian socialists endorsed free trade a few years earlier. See Michael Huberman, 'Ticket to Trade: Belgian Labour and Globalization Before 1914', Economic History Review 61 (May 2008): 326-359. Engels himself had long been encouraging the SPD to oppose these protectionist measures. Engels to Bebel, 24 Nov. 1879, reprinted in MECW vol. 45, 423. Hoselitz, 'Socialism, Communism, and International Trade', 233. On Bebel's condemnation of colonialism and tariff wars, see his 'Socialism and Internationalism', Social Democrat 9 (15 Aug. 1905), 491-493.

${ }^{50}$ Lichtheim, Marxism, 287fn, 275fn.

${ }^{51}$ Roger Chickering, Imperial Germany and a World Without War: The Peace Movement and German Society, 1892-1914 (Princeton, 1975), 276.
} 
Marx-Manchester tradition: '(1) The freedom of subject races of nationalities, (2)

Steps towards disarmament, and (3) Steps towards world-wide free trade.' As one American socialist described the latter proposal, Kautsky's vision was 'a world-wide economic interdependence of nations that would soon bring it about that wars would be neither economically desirable nor economically feasible. ${ }^{52}$

Kautsky's cosmopolitan vision bore an uncanny likeness to that laid out just a handful of years earlier by Manchester School journalist Norman Angell, who had argued that war was economically futile owing to the era's unprecedented global market interdependence in his international bestselling book The Great Illusion (1910). The similarity between Kautsky and Angell's arguments was doubtless more than coincidental. In 1913 German pacifists had made sure to distribute 2,000 German translations of Angell's book (Illusion, Die Falsche Rechnung), as well as 40,000 fifteen-page pamphlets containing its key arguments, in advance of Angell's notorious speaking tour of German universities. ${ }^{53}$

As the world war progressed, more and more international peace activists, Marxist and non-Marxist alike, envisaged a more peaceful economically interdependent postwar world. The 1916 Socialist Peace Conference held at The Hague - which included delegates from Spain, the United States, Denmark, Sweden, Argentina, and Holland — adopted resolutions 'condemning an economic war after the war and favoring free trade and freedom of the seas. ${ }^{54}$ And the mixture of Manchester liberal and Marxist attendees of the First American Conference for Democracy and Peace in 1917 at New York's Madison Square Garden drew attention

\footnotetext{
${ }^{52}$ William English Walling, Socialists and the War (New York, 1915), 443, 444.

${ }^{53}$ Philip D. Supina, 'The Norman Angell Peace Campaign in Germany', Journal of Peace Research 9 (1972): 161-164; Chickering, Imperial Germany and a World Without War, 180-81.

54 'Socialist Peace Conference', Information Quarterly 2 (Oct. 1916), 462. The delegates from Switzerland, Luxemburg, Norway, and Rumania were unable to attend.
} 
to how their shared belief in free trade and peace had brought them together. Morris Hillquit, the international secretary of the Socialist Party of America, reported on the endorsement of worldwide 'freedom of commerce' from the conference's Committee on Peace. 'We are trading in a world market. Economically and commercially, it is one,' and yet 'people have tried to parcel out this world into rigid nations or countries with rigid boundary lines, separated from each other by various and conflicting treaties and customs, duties and other artificial restrictions' that ultimately led to world war. ${ }^{55}$

Such activism became a groundswell between 1917 and 1918, owing in large part to Wilson's Manchester School-inspired Fourteen Points and the newly announced peace program of the Soviet government. In Britain, the 1917 National Labour Conference held in Manchester gave its socialist backing to Woodrow Wilson's 'international league for peace,' and passed its own resolution demanding 'free trade for every country.' ${ }^{56}$ The following year, Max Eastman, with his sister Crystal Eastman, began co-editing the American communist magazine the Liberator. Max, 'as an international socialist, welcomed Wilson's "Program of the World's Peace," including its support for 'renouncing economic war on Germany' and 'freetrade and the principle of the open door everywhere. ${ }^{57}$ In early 1918 , the National Executive Council of the Socialist Party of America issued a memorial to Wilson, giving its unreserved anti-imperial endorsement to 'the peace program of the Russian Socialist government,' which included a call for freedom of the seas and 'full equality of trade conditions among all nations,' and asked Wilson to take part in the Russian-

\footnotetext{
${ }^{55}$ Report of the First American Conference for Democracy and Terms of Peace, May $30^{\text {th }}$ and $31^{s t}$, 1917 (New York City, 1917), 19-12, 33-34.

56 'Brief Peace Notes', Advocate for Peace 79 (March 1917), 88.

${ }^{57}$ Max Eastman, 'A World's Peace', Liberator 1 (March 1918), 8.
} 
Central Powers peace conference. ${ }^{58}$ The 1918 Congressional Program of the Socialist

Party similarly echoed the Soviet government's peace program, while adding 'to the

famous formula. . . 'No economic nationalism, no war after the war." ${ }^{59}$ Lacking the context of the Marx-Manchester free-trade tradition, such international socialist support for Wilson's Manchester liberal economic vision might seem striking. After all, there was no love lost between US socialists and the Wilson Administration, which had persecuted, censored, and even jailed them during the war. ${ }^{60}$ And yet their shared internationalist vision of a postwar world of free trade and peace allowed them to transcend their mutual antagonism.

Socialist free-trade-and-peace activism increasingly became one of international collaboration. With radical socialist academic Scott Nearing presiding, Harlem's 1918 National Conference of Labor, Socialist, and Radical Movements developed a peace program demanding self-determination, disarmament, freedom of the seas, free migration, and that 'free trade should prevail.' The program was then sent to Germany, Italy, France, and England for 'approval and support.' ${ }^{61}$ Nearing, an officer of the Boston-based peace organization the International Free Trade League (IFTL), also made sure to send a copy of the Harlem program to IFTL president Frank Wright Garrison, a grandson of Boston's mid-nineteenth-century arch-

\footnotetext{
58 'Memorial: To the President and Congress of the United States from the NEC of the Socialist Party of America, February 1918', Eye Opener [Chicago] 9 (16 Feb. 1918), 4.

59 'Socialist Party Congressional Program', reprinted in Liberator 1 (Oct. 1918), 42, 44.

${ }^{60}$ David M. Kennedy, Over Here: The First World War and American Society (Oxford, 2004 [1980]), 70-86, 355-357; Arno Mayer, Wilson versus Lenin: Political Origins of the New Diplomacy, 19171918 (New Haven, 1959); Georg Schild, Between Ideology and Realpolitik: Woodrow Wilson and the Russian Revolution, 1917-1921 (Wesport, CT, 1995). On the false Wilsonian promise to undermine the imperial order, see Erez Manela, The Wilsonian Moment: Self-Determination and the International Origins of Anticolonial Nationalism (Oxford, 2007); Susan Pedersen, The Guardians: The League of Nations and the Crisis of Empire (Oxford, 2015).

61 'Program and Resolutions of the Labor, Socialist and Radical Movements of the United States', reprinted in Bulletin of the People's Council of America 1 (1 March 1918), 6; 'Pacifists Glorify Bolshevik "Victory,"' New York Times, 17 Feb. 1918, 14; 'A Working-Class Peace', Liberator 1 (April 1918): 7-8.
} 
abolitionist Cobdenite William Lloyd Garrison. Frank shared his family's radical progressive position on social and economic issues. A fervent non-Marxist disciple of Henry George and Richard Cobden, Frank nevertheless gave Nearing's socialist program his blessing, owing to the fact that 'economic freedom heads the list and is thoroughly sound and uncompromising. ${ }^{62}$ Just half a year later in London, similar socialist motions were made at the Inter-Allied Labor Conference. The conference roundly condemned (1) 'the colonial policy of capitalist Governments'; (2) 'economic aggression, whether by protective tariffs or capitalist trusts or monopolies'; and (3) 'the alliance between the Military Imperialists and the Fiscal Protectionists in any country whatsoever' as a 'grave menace to peace' and to the prosperity of the working class. ${ }^{63}$

The rapidly expanding Marx-Manchester tradition, however, did not maintain a complete monopoly on late-nineteenth and early-twentieth-century socialist thought. Although less prominent at this time, what might be called a Marx-List tradition was evolving alongside it. German-American protectionist theorist Friedrich List had argued in his influential book The National System of Political Economy (1841) that developing nations' infant industries required a combination of colonialism and protectionism to catch up to more advanced states like mid-nineteenth-century Britain; universal free trade ought to occur only once worldwide developmental parity was achieved at some undefined point down the road. List's protectionist theory was a critique of British free-trade imperialism. But it also issued a

\footnotetext{
${ }^{62}$ Frank Wright Garrison to William Lloyd Garrison III, 15 Feb. 1918, Box 76, Folder 5, Garrison Family Papers, Sophia Smith Collection, Smith College, Northampton, MA.

63 'Memorandum on War Aims. Adopted by the Inter-Allied Labour and Socialist Conference in London February 22, 1918', reprinted in Labor's War Aims (June 1918), 190, 192; Proceedings of the Inter-Allied Labor Conference, London, September 17, 18, 19, 1918 (Washington D.C., 1918), 10, 48. The conference's endorsement of the principle of the open door even earned it some reluctant praise from the New York Times. See 'Plans for Socialistic World', New York Times, 22 Sept. 1918, 47.
} 
protectionist call for colonial expansion among developing states like Germany and the United States, which List believed needed to acquire raw materials and captive protective markets to invest their surplus capital. ${ }^{64}$

Despite Marx's own strong criticisms of List's theories, some more nationalistic socialists ended up drawing on his ideas to bolster their nations' protectionist imperial policies. When Britain adopted free trade in the $1840 \mathrm{~s}$, for example, numerous nationally-focused French socialists disavowed free trade owing both to the longstanding rivalry between the two countries and to the growing influence of List's Anglophobic theories within French politics. ${ }^{65}$ In turn-of-thecentury Britain, Fabian socialists like George Bernard Shaw were throwing their support behind protectionism and British imperial expansion. ${ }^{66}$ Although a free-trade utopian in the 1880s while under the influence of American Cobdenite Henry George, by 1904 Shaw sought to counter the British socialist predilection for free trade by insisting that British socialism was 'ultra-Protectionist' and required imperial federation to obtain social reform. ${ }^{67}$ British Clarion socialists, even more than Fabian's like Shaw, viewed foreign trade as a zero-sum game. By 1910 the Clarion socialists began running a strong pro-Tariff Reform campaign assailing 'The Liberal-

\footnotetext{
${ }^{64}$ Onur Ulas Ince, 'Friedrich List and the Imperial Origins of the National Economy', New Political Economy 21 (2016): 380-400; Mauro Boianovsky, 'Friedrich List and the Economic Fate of Tropical Countries', History of Political Economy 45 (Winter 2013): 647-691; Keith Tribe, 'Friedrich List and the Critique of "Cosmopolitical Economy,"” Manchester School of Economic and Social Studies 56 (March 1988): 17-36; Henryk Szlajfer, Economic Nationalism and Globalization, trans. by Maria Chmielewska-Szlajfer (Leiden, 2012); David Levi-Faur, 'Friedrich List and the Political Economy of the Nation-State', Review of International Political Economy 4 (1997): 154-178.

${ }^{65}$ David Todd, Free Trade and Its Enemies in France, 1814-1851 (Cambridge, 2015), 146-154, 187$189,191,216-220$. Some French socialist internationalists came around to free trade by the turn of the century. See Suzanne Berger, Notre Première Mondialisation: Leçons d'un Échec Oublié (Paris, 2003).

${ }^{66}$ Gregory Claeys, Imperial Sceptics: British Critics of Empire, 1850-1920 (Cambridge, 2010), 185198; Thompson, 'Hobson and the Fabians', 212-213; Trentmann, 'Wealth versus Welfare', 88-96; Bernard Porter, Critics of Empire: British Radicals and the Imperial Challenge (London, 2008), 111123.

${ }^{67}$ Mark Bevir, 'The Marxism of George Bernard Shaw 1883-1889', History of Political Thought 13 (Summer 1992), 305; George Bernard Shaw, Fabianism and the Fiscal Question (London, 1904), 9; Peter Clarke, Liberals and Social Democrats (Cambridge, 1978), 89-90
} 
Free Trade-Labour Party. ${ }^{68}$ Attempts were also made in Germany to wed List's ideas to the SPD. Along Listian and Lassallian lines, the SPD's minority cohort of Marxist protectionists like Paul Lensch gave their nationalistic stamp of approval to German imperial expansion. ${ }^{69}$

In quite different economic imperial contexts, some turn-of-the-century Indian anti-colonial nationalists also began turning to a combination of Marx and List for inspiration. The key difference arose in that, whereas the British settler colonies were granted fiscal autonomy, India was forced to keep its tariffs low and to produce raw materials for British manufacturers, to the detriment of India's own industrial development. Second, where socialist nationalists in France, Germany, and Britain embraced List's protectionist call for colonizing undeveloped states, List's Indian disciples focused upon his critique of British free-trade imperialism. ${ }^{70}$ This anticolonial strand of the Marx-List tradition, to which Manu Goswami has redrawn attention, would resurface in an even bigger way after 1945 among nationalists throughout the Global South. But in the decades immediately following the First World War, advocacy of this Marx-List tradition remained the exception to what was fast becoming the Marx-Manchester rule.

IV. Marx-Manchester Free-Trade Internationalism, c. 1919-1946

\footnotetext{
${ }^{68}$ Trentmann, 'Wealth Versus Welfare', 89-93.

${ }^{69}$ Abraham Ascher, 'Radical' Imperialists within German Social Democracy, 1912-1918', Political Science Quarterly 76 (Dec. 1961), 561, 570-571; Lichtheim, Marxian Socialism, 96-99, 287. See, also, Alfred Meusel, List und Marx (Jena, 1928).

${ }^{70}$ Manu Goswami, Producing India: From Colonial Economy to National Space (Chicago, 2004), chap. 7. On British free-trade imperialism in India, see especially Peter Harnetty, Imperialism and Free Trade: Lancashire and India in the Mid-Nineteenth Century (Vancouver, 1972).
} 
Interwar Europe became a breeding ground of socialist free-trade-and-peace activity, maintained and regulated, they argued, through a league of nations. Socialist intellectuals like Albert Einstein thought of free trade as a peace movement. ${ }^{71}$ In order to create a more peaceful geopolitical order, the socialist parties of France, Germany, Austria, Britain, and Hungary came out in support of international freedom of the seas and freedom of trade in 1919. That year's International Socialist Congress in Berne also endorsed these pacific free-trade positions, coupled with 'the Socialist ideal of a League of Nations' endowed with the power to regulate interstate trade and to control 'world thoroughfares' and 'the production and distribution of foodstuffs and raw materials throughout the world. ${ }^{72}$ The Marx-Manchester association of protectionist monopolies with the imperial search for new markets and natural resources meant that they saw no contradiction in calling for universal free trade alongside supranational regulation and distribution of raw materials; both were deemed necessary to undermine the economic foundations of colonialism and militarism.

Boston feminist Crystal Eastman and her brother Max played a key part in entwining the US socialist, free trade, and peace movements through their Marxist magazine the Liberator. Crystal Eastman took the opportunity as co-editor to spread the word about the newly formed IFTL (like Nearing, she was an IFTL officer), placing a full-page advert immediately after the front-page visage of Lenin in the January 1919 issue. Along clear Cobdenite lines of argument, the advert made sure to

\footnotetext{
${ }^{71}$ Francis Neilson, My Life in Two Worlds: Volume Two 1915-1952 (Appleton, WI, 1953), 144. See, also, Albert Einstein to Heinrich Zangger, 21 Aug. 1917, Einstein Archives Online 89-523; David E. Rowe and Robert Schulmann, Einstein on Politics (Princeton, 2007), 77; The Institute for Intellectual Cooperation, 16 Jan. 1926, Einstein Archives Online 28-037; Einstein on Politics, 200.

${ }^{72}$ International Socialism and World Peace: Resolutions of the Berne Conference, February, 1919 (London, 1919), 4. Australian socialists were making similar motions. See 'The World's Peace', Daily Standard (Brisbane, Queensland), 16 Jan. 1919, 3.
} 
stress the connection between free trade and peace. Free trade was the 'only secure foundation' for the League of Nations. Free trade's panacea would also end the colonial question, protect small nations, end militarism, provide cheap goods, lower the cost of living, create global prosperity, and establish permanent peace.

'International Free Trade' therefore must be 'incorporated in the Peace Treaty as repeatedly recommended by (1) President Wilson, (2) the British Labor Party, (3) the German Reichstag, (4) the Russian People's Government, and (5) Socialists everywhere. ${ }^{73}$

The Western embargo of the new Soviet government from 1919-21 also became a hot-button issue for socialist free traders. IFTL officer Ludwig Martens, the Soviet Government's official representative to the United States between 1917-21, with the assistance of Santeri Nuorteva - a Finnish Marxist politician, journalist, and fellow IFTL officer — worked hard to obtain US loans and end the embargo from their Soviet Bureau offices in New York. Under the suspicious watch of the US Government, their organization's Marxist publication Soviet Russia began propagandizing how normalization of trade would make 'a real peace' and alleviate the mass starvation of Eastern Europe. ${ }^{74}$

Socialist free traders in interwar Britain wielded considerable influence in national and international politics and were among the country's lead defenders of Manchester liberalism. While some heterodox British socialists supported protectionism and imperialism, the Labour Party itself remained a melting pot of socialist and Manchester liberal economic ideas. As Frank Trentmann notes, Labour

\footnotetext{
73 'Free Trade', Liberator 2 (Jan. 1919), 2.

${ }^{74}$ Katherine A. S. Siegel, Loans and Legitimacy: The Evolution of Soviet-American Relations, 1919 1933 (Lexington, 1996); 'From Trade to Peace', Soviet Russia, 25 June 1920, 639. See also Soviet Russia, 7 June 1919, 11; 20 March 1920, 292. Crystal Eastman was similarly happy to note that the U.S. Socialist Party platform included an anti-embargo call for free trade. Crystal Eastman, 'The Socialist Party Convention', Liberator 3 (July 1920), 25.
} 
inherited the Liberal radical 'belief that trade promoted the brotherhood of man by

breaking down the walls of insular prejudice and chauvinism associated with

protectionist imperialism': a 'socialist-radical dualism.' Leading Manchester liberal

internationalists, including Norman Angell, J. A. Hobson, H. N. Brailsford, and

Bertrand Russell, had associated themselves more strongly with progressive social

reform during the Edwardian period - New Liberalism - helping to pave the way for

Labour's postwar popularity. ${ }^{75}$ Owing in no small part to this confluence of 'new'

Manchester liberalism with Labour socialism, opposition to protectionism remained a

key part of British socialist peace activism well into the 1930s and 1940s. The first

position the Labour Party laid out in its 1923 manifesto was an indictment of

protectionism 'and the whole conception of economic relations underlying it. ${ }^{76}$

Following the National Government's abandonment of free trade for imperial

\footnotetext{
${ }^{75}$ Lucian M. Ashworth, 'Democratic Socialism and International Thought in Interwar Britain', in I. Hall, ed., Radicals and Reactionaries in Twentieth-Century International Thought (New York, 2015): 75-100; P. J. Cain, Hobson and Imperialism: Radicalism, New Liberalism, and Finance 1887-1938 (Oxford, 2002), chap. 7; Noel Thompson, 'Hobson and the Fabians: Two Roads to Socialism in the 1920s', History of Political Economy 26 (Summer 1994), 212-213; Jules Townsend, 'Hobson and the Socialist Tradition', in J. Phelby, ed., J. A. Hobson after Fifty Years: Freethinker of the Social Sciences (Basingstoke, 1994): 34-52; Paul Mulvey, The Political Life of Josiah C. Wedgwood: Land, Liberty and Empire, 1872-1943 (Suffolk, 2010), 125; Howard Weinroth, 'Norman Angell and the Great Illusion: An Episode in Pre-1914 Pacifism', Historical Journal 17 (Sept. 1974), 554fn.9, 555-56, 562, 572-73; Trentmann, 'Wealth versus Welfare', 91; Frank Trentmann, 'The Strange Death of Free Trade: The Erosion of "Liberal Consensus" in Great Britain, c. 1903-1932', in Biagini, ed., Citizenship and Community, 233-35, 242-245; J. E. King, 'Popular Philosophy and Popular Economics: Bertrand Russell, 1919-70', Russell: Journal of Bertrand Russell Studies 27 (Winter 2007-08), 203-205, 212-13. On Brailsford's socialist support for Cobdenism, see, for instance, Henry Noel Brailsford, A League of Nations (New York, 1917), chap. 9; Brailsford, The War of Steel and Gold (London, 1918), esp. 32829.

${ }^{76} 1923$ Labour Party General Election Manifesto (1923); Trentmann, Free Trade Nation, 311. On British socialism and anti-imperial and peace activism, see especially Claeys, Imperial Sceptics; Martin Ceadel, Pacifism in Britain 1914-1945: the Defining of a Faith (Oxford, 1980); Stephen Howe, Anticolonialism in British Politics: The Left and the End of Empire, 1918-64 (Oxford, 1993); Porter, Critics of Empire; Richard Price, An Imperial War and the British Working Class (London, 1972); Partha Sarathi Gupta, Imperialism and the British Labour Movement, 1914-1964 (London, 1975); Billy Frank, Craig Horner, and David Stuart, eds., The British Labour Movement and Imperialism (Newcastle upon Tyne, 2010); Martin Shaw, 'War, Peace and British Marxism, 1895-1945', in Taylor and Young, eds. Campaigns for Peace (Manchester, 1987): 49-72; Lucian M. Ashworth, 'Democratic Socialism and International Thought in Interwar Britain', in I. Hall, ed., Radicals and Reactionaries in Twentieth-Century International Thought (London, 2015): 75-100; Peter Lamb, 'The British Left in the Problems of Peace Lectures, 1926-38: Diversity that E. H. Carr Ignored', International History Review 36 (2014): 530-549.
} 
preference in 1932, Labour's 1934 publication For Socialism and Peace attacked 'the disastrous economic nationalism of the present age by working for an all-round lowering of tariffs' through 'a system of planned international exchange.' Labour's support for a domestic planned economy in the early 1940s, in turn, was coupled with a call for a supranational body that would oversee a new era of multilateral free-trade agreements and international control of raw materials. ${ }^{77}$

More and more international socialist organizations in interwar Europe also began giving their pacific free-trade blessing to supranational governance. The Labour and Socialist International (LSI), the more inclusive rival of the Comintern, looked for a middle way between Marxism and liberal radicalism in its search for peace. ${ }^{78}$ Revitalized in 1923, the LSI called for 'permanent peace'; supported the League of Nations; condemned capitalist imperialism; and demanded that 'labour must also fight against protectionism and in favour of free trade' and the free movement of people. The socialist International Federation of Trade Unions (IFTU, 1919-1945), an avowed peace organization based in Amsterdam with close ties to the LSI, likewise endorsed universal free trade and the liberal internationalist vision embodied in the League of Nations. ${ }^{79}$

The Marx-Manchester peace movement received an interwar boost from the resurgent international co-operative movement, which advocated for an economic 'third way' situated between individualism and collectivism, and between liberal reform and socialist revolution. The international co-operative movement had come a

\footnotetext{
${ }^{77}$ Labour Party, For Socialism and Peace (London, 1934), 8-9, 11; Richard Toye, The Labour Party and the Planned Economy, 1931-1951 (London, 2003), 158-162.

${ }^{78}$ Daniel Laqua, 'Democratic Politics and the League of Nations: Labour and Socialist International as a Protagonist of Interwar Internationalism', Contemporary European History 24 (May 2015), 192.

${ }^{79}$ Resolutions of the International Labour Congress of Socialist Parties, Hamburg 1923, pp. 7, 14, 1617; J. W. Brown, 'The International Trade Union Movement', Journal of the Royal Institute of International Affairs 7 (Jan. 1928): 29-41; Laqua, 'Democratic Politics and the League of Nations.'
} 
long way from its modest origins in 1840s Rochdale, England, a town with strong Cobdenite roots. ${ }^{80}$ By the 1920 s, the movement's umbrella organization, the International Co-operative Alliance (ICA), rivaled the international trade union movement as the interwar world's largest transnational non-governmental organization. ${ }^{81}$ Its peaceful economic vision was a social democratic one focused upon a grassroots, not-for-profit, working-class version of free trade that would empower the world's consumers and local producers alike. To accomplish this and to undermine international trusts and cartels, co-operative free trade also called for supranational control over the global distribution of food and raw materials through the League of Nations. ${ }^{82}$

The predominant interwar international co-operative movement embodied the Marx-Manchester ideological paradigm in its grassroots efforts to promote worldwide prosperity and peace through co-operative free trade. The Women's Co-operative Guild (WCG, 1893), a feminist peace organization that maintained close ties to the British Labour Party, had given its formal endorsement to free trade by the turn of the century, pointing its members to the free-trade activism of socialist workers in Germany for inspiration. ${ }^{83}$ The ICA had embraced pacifism a bit later than the WCG, endorsing peace and world federalism in 1913 in the hopes of stopping the world war before it began. ${ }^{84}$ At war's end, the ICA drew up a memorandum to send to the Paris

\footnotetext{
${ }^{80}$ Peter Gurney, Wanting and Having: Popular Politics and Liberal Consumerism in England, 1830 70 (Manchester, 2014), 263.

${ }^{81}$ Friberg, 'A Co-operative Take on Free Trade', 211.

${ }^{82}$ Friberg, 'A Co-operative Take on Free Trade', 214-215.

${ }^{83}$ Women's Free Trade Demonstration (Manchester, 1903), in Folder DM 851, Miscellaneous 19011911, Jane Cobden Unwin Papers, Special Collections Library, University of Bristol (Bristol, UK); Naomi Black, 'The Mothers' International: The Women's Co-operative Guild and Feminist Pacifism', Women's Studies International Forum 7 (1984): 467-476.

${ }^{84}$ Report of the Proceedings of the Ninth Congress of the International Co-operative Alliance held at Glasgow 1913; Katarina Friberg, 'A Co-operative Take on Free Trade: International Ambitions and Regional Initiatives in International Co-operative Trade', in Mary Hilson, Silk Neunsinger, and Greg
} 
Peace Conference that connected peace with a League of Nations that embraced cooperative free trade. ${ }^{85}$ The co-operative movement remained prominent within the interwar peace movement, keeping up its League of Nations lobbying campaign on behalf of its particular brand of Marx-Manchester free trade. ${ }^{86}$

By the end of the 1920s, however, rifts had begun to develop between the international co-operative movement's more moderate socialist majority and the more radical representatives of the Soviet co-operatives, who instead saw cooperation as a means to socialist revolution. ${ }^{87}$ The latter expressed their disappointment that the ICA had failed to explicitly endorse the principle of class struggle. They also criticized ICA leaders for continuing to seek co-operative free-trade-and-peace reforms through the liberal capitalist League of Nations. The Soviet members instead argued that, as Katarina Friberg puts it, "only the "United States of the Soviet Republics" could achieve real free trade. ${ }^{, 88}$ For Soviet advocates of 'real free trade' like the cooperatives and Lenin himself, the meaning of the term itself was transforming into an economic policy to be practiced only between socialist planned economies rather than between all the world's producers and consumers as advocated by the era's Marx-Manchester international disciples.

The world economic crisis of the 1930s and the consequent global turn to economic autarky, nationalism, and imperial consolidation only reaffirmed the MarxManchester tradition for its socialist internationalist subscribers. They continued to connect protectionism with imperialism and militarism, and free-trade

Patmore, eds., A Global History of Consumer Co-operation Since 1850 (Leiden, 2017), 211; Rhodes, International Co-operative Alliance, 28-31.

${ }^{85}$ Friberg, 'A Co-operative Take on Free Trade', 212.

${ }^{86}$ See, for instance, Joy Emmanuel and Ian MacPherson, eds., Co-operatives and the Pursuit of Peace: Vol. 1 (Vancouver, 2007).

${ }^{87}$ Bruno Jossa, 'Marx, Marxism and the cooperative movement,' Cambridge Journal of Economics 29 (2005): 3-18; Jossa, 'Marx, Lenin and the Cooperative Movement,' Review of Political Economy 26 (May 2014): 282-302.

${ }^{88}$ Friberg, 'A Co-operative Take on Free Trade', 203-205, 219. 
internationalism with peace. The SPD's Rudolf Hilferding, recently removed from his position as Germany's minister of finance, wrote in 1931 in favor of international cooperation under the auspices of the League of Nations's International Labour Organization in order to substitute the "chaos wrought by economic nationalism with a well-planned order' of global exchange. ${ }^{89}$ Even as Britain itself was abandoning its long-held free-trade orthodoxy for imperial trade preference and the Soviet Union was becoming ever more closed off, the Executive Committee of the Comintern explained at its 1932 meeting in Moscow knew where to lay the brunt of the blame: 'The fierce struggle the imperialists are waging for markets and colonies, the tariff wars and the race for armaments, have already led to the immediate danger of a new imperialist world war. ${ }^{90}$ A similar refrain was heard from the 2,196 socialists from India, China, Japan, the Balkans, South America, the United States, and Western Europe - claiming to represent 30,000 organizations and 30,000,000 workers of the world — that attended the World Congress Against War in Amsterdam in 1932. Its manifesto blamed the protectionist measures 'adopted under the pressure of the economic crisis' for deepening it and for rendering 'inevitable the transformation of economic rivalry into armed conflict. ${ }^{91}$ The international co-operative movement also mobilized on behalf of free trade and peace throughout the 1930s. ${ }^{92}$

\footnotetext{
${ }^{89}$ Hilferding, 'Kongress der S.A.I. 1931', 2, C.234/31 (169/7), available online at https://search.socialhistory.org/Record/ARCH01368\#A0e32ab60b1 via SAI; Shaev, 'Liberalizing Regional Trade', 265.

${ }^{90}$ Matthew Stubbings, 'Free Trade Empire to Commonwealth of Nations: India, Britain and Imperial Preference, 1903-1932', International History Review 41 (2019):323-344; John Willoughby, 'The Changing Role of Protection in the World Economy', Cambridge Journal of Economics 6 (June 1982), 196; 'Extracts From the Theses of the Twelth Ecci Plenum on the International Situation and the Tasks of the Comintern Sections', in Jane Degras, ed., Communist International, 1919-1943: Documents (3 Vols., Oxford, 1956) iii: 223.

${ }^{91}$ Report and Manifesto of the World Anti-War Congress at Amsterdam August $27^{\text {th }}-29^{\text {th }}, 1932$ (1932). British Marxist Sue Cockerill sounded this same free-trade internationalist note in 1980 in 'Reply to Left Reformism', International Socialism 2 (1980). Similarly, see 'Reply of the Young Communist International to the Questions Raised in the 'Study Plan',' 8, Box 213.08.3, Student Christian Federation Papers, World Council of Churches, Geneva, Switzerland; 'The Programme of the
} 
Owing to the growing economic nationalist trend across the globe, socialist internationalist supporters of free trade found themselves increasingly at odds not only with the capitalist powers of the West, but also with the ostracized Soviet east, as its foreign trade became ever more autarkic under Stalin's autocratic 'socialism in one country' rule. Kautsky, for example, admonished the Soviet monopoly of foreign trade, arguing that the latest economic nationalist uptick was contributing to the growth of fascism. ${ }^{93}$ In contrast to the Soviet Union, socialist internationalists in Germany and France sought instead to toe the free-trade-and-peace line, including supporting liberal capitalist supranational organizations to oversee its regulation. Germany's SPD and the French Socialist Party, according to Brian Shaev, 'became the largest political forces in their countries committed to liberalising international trade. ${ }^{94}$ And in 1943, while the Second World War raged, the French Socialist Party became adamant in calling for a 'United States of Europe' as a necessary first step towards a 'United States of the World,' empowered with the ability to regulate and monitor customs tariffs. ${ }^{95}$

Just a year before, however, Vienna-born Marxist intellectual Franz Borkenau had criticized the pervasive Marx-Manchester vision for a global economic order of supranational governance, free trade, and peace. In Socialism: Nationalism or Internationalism (1942), written from London, he argued that internationalism was 'not socialist but a liberal ideal, borrowed by socialists from the liberals of their age.' Marx himself had 'carried the convictions and the prejudices of the liberal age into

Communist International Adopted at its Sixth Congress', in Degras, ed., Communist International, II: 478.

${ }^{92}$ Friberg, 'A Co-operative Take on Free Trade', 222-23.

${ }^{93}$ Massimo Salvadori, Karl Kautsky and the Socialist Revolution, 1880-1938, trans. by Jon Rothschild (London and New York, 1990), 305, 350.

${ }^{94}$ Hilferding, 'Kongress der S.A.I. 1931', 2, C.234/31 (169/7), available online at https://search.socialhistory.org/Record/ARCH01368\#A0e32ab60b1 via SAI; Shaev, 'Liberalizing Regional Trade', 265.

${ }^{95}$ Shaev, 'Liberalizing Regional Trade', 269. 
the labour movement. It is now necessary to say that the Marxists were as ready to carry into the labour movement the convictions and the prejudices of the bourgeoisie of a later day.' For Borkenau, the Marx-Manchester panacea of a new economic order based upon 'international free trade and international planning, absolute selfdetermination of nations and federal union to the exclusion of all sovereignties' was a pipedream. He also discounted the 'Hobson-Hilferding-Lenin' theory of imperialism; its association of protectionist monopoly capitalism with imperial expansion was but 'more proof of the overwhelming influence of liberalism upon early socialism.' Socialist 'neo-liberal utopians, of the Federal Union type' were similarly mistaken in seeking to devise an equitable and democratic "second, "more efficient" edition of the League of Nations' for governing a new age of free trade and peace. Soviet Russia's embrace of economic nationalism, the worldwide turn to fascism and autarky after the Great Depression, the unequal levels of global economic development, and worldwide racial conflict all proved such 'utopian' socialist internationalist dreams delusional. ${ }^{96}$

Just such a Marx-Manchester 'utopian' planned supranational vision of free trade and peace prevailed not only among European socialist federal unionists, but also among socialist internationalists in 1930s and 1940s America. Under the political and intellectual leadership of Norman Thomas and Scott Nearing, American socialists renewed their Marx-Manchester commitments in response to the Great Depression and continued Republican protectionism. Thomas - a prominent interwar pacifist

\footnotetext{
${ }^{96}$ Franz Borkenau, Socialism: National or International (London, 1942), 37-38, 91, 69, 89, 162. On mid-century transatlantic liberal and socialist debates over postwar 'federal union', see Tommaso Milani, 'From Laissez-Faire to Supranational Planning: The Economic Debate within Federal Union (1938-1945)', European Review of History 23 (March 2016): 664-685; Or Rosenboim, 'Barbara Wootton, Friedrich Hayek and the Debate on Democratic Federalism in the 1940s', International History Review 36 (2014): 894-918' Peter Lamb, 'Harold Laski's International Functionalism: A Socialist Challenge to Federalism', International History Review 41 (2019): 581-603.
} 
and anti-imperialist, and the Socialist Party's six-time presidential nominee between 1928-48 — believed that the only way to end war was to reform the world economic system through a combination of Cobdenism, international socialism, co-operativism, and supranational regulation of food and raw materials. ${ }^{97}$ Under his leadership, the Socialist Party of America made sure to single out the GOP's protectionist 1930 Smoot-Hawley Tariff, calling it 'the most monstrous tariff legislation in the history of the country. . . It has, in effect, declared economic war against the rest of the world and served to aggravate the instability of world economy and world trade. ${ }^{98}$ Nearing took to task not only US protectionism, but also the European turn to autarky and fascism. 'Theory denies the possibility of economically self-sufficient twentieth century nations. But fascists are not concerned with theory . . . they propose to make autarchy work. ${ }^{99}$ Western Europe, he argued, 'builds the frontiers of each nation every higher, with tariffs, subsidies, quotas, immigration prohibitions. . . The pursuit of this autarchic goal is driving West Europe steadily toward' economic sectionalism, militarism, and geopolitical conflict. ${ }^{100}$ The Socialist Party of America's advocacy of free trade remained a key ingredient of its peace program well into the postwar years, as did various other socialist parties in Europe seeking regional and international economic interdependence as a prerequisite for peace. ${ }^{101}$

\section{Conclusion}

\footnotetext{
${ }^{97}$ Norman Thomas, The Challenge of War: An Economic Interpretation (New York, 1923), 9-11, 3233, 36-37.

${ }^{98}$ Trentmann, 'Strange Death of Free Trade', 248; Declaration of Principles of the Socialist Party in the 1930 Congressional Campaign (Chicago, 1930), 1, in 'Socialism', Folder 3, Box 20, Alice Park Papers, Hoover Institution, Stanford University, Palo Alto, CA.

${ }^{99}$ Scott Nearing, Fascism (Ridgwood, NJ, 1930), 47

${ }^{100}$ Scott Nearing, Europe: East and West (Ridgewood, NJ, 1934), 42-45.

${ }^{101}$ Shaev, 'Liberalizing Regional Trade'.
} 
What would become a widespread early- to mid-twentieth-century socialist internationalist belief that free trade was a prerequisite for world peace originated in 1840s Britain, amid the heyday of Manchester liberalism. Building on Marx and Engels's qualified mid-nineteenth-century endorsement of free trade, socialist internationalists thereafter borrowed from, inspired, and at times even worked alongside capitalist disciples of Manchester liberalism owing to their shared desire to overturn the militant economic nationalist world order that prevailed over the late nineteenth and early twentieth centuries. By the 1920s, 1930s, and 1940s, they also shared a similar belief that supranational governance would be needed to regulate and maintain a freer, more peaceful, and interdependent global marketplace: a vision for a new international economic order that informed the post-1945 globalization projects of the capitalist West, the socialist East, and the Global South. ${ }^{102}$ On the eve of the Cold War, socialist internationalists continued to draw upon a free-trade tradition that shared a common heritage with that of the mid-twentieth-century capitalist heirs of Manchester liberalism. As a result, both camps supported the shaping of a new economic cosmopolitan order. However, whether the peace and prosperity wrought from worldwide free trade was the desired end goal in itself — as it was for Manchester School capitalists like Cordell Hull and Friedrich Hayek — or whether this was seen as the next peaceful step towards a socialist global order remained the point of essential divergence.

\footnotetext{
102 Or Rosenboim, The Emergence of Globalism: Visions of World Order in Britain and the United States, 1939-1950 (Princeton, 2016); Slobodian, Globalists; Richard Toye, 'Developing Multilateralism: The Havana Charter and the Fight for the International Trade Organization, 19471948,' International History Review 25 (2003): 282-305; Talbot C. Imlay, 'Exploring What Might Have Been: Parallel History, International History, and Post-War Socialist Internationalism,' International History Review 31 (2009): 521-557; James Mark, Artemy M. Kalinovsky, and Steffi Marung, eds., Alternative Globalizations: Eastern Europe and the Postcolonial World (Bloomington, 2020); Mark, Iacob, Rupprecht, and Spaskovska, 1989, chap. 1; Johanna Bockman, 'Socialist Globalization against Capitalist Neocolonialism: The Economic Ideas behind the New International Economic Order,' Humanity 6 (Spring 2015): 109-128.
} 
